\title{
Waiver of the Attorney-Client Privilege by the Trustee in Bankruptey
}

The filing of a bankruptcy petition ${ }^{1}$ alters the way decisions about the deployment of the debtor's ${ }^{2}$ assets are made. Such changes fulfill the basic purpose of bankruptcy: to preserve and enhance the debtor's assets and to satisfy, as far as possible, the claims of the debtor's investors (i.e., all parties with legal claims against the debtor) $)^{3}$ through a collective proceeding. One of the most significant of these changes is the appointment of a trustee to administer the debtor's estate. ${ }^{\mathrm{s}}$ The Bankruptcy Code (the

1 Bankruptcy petitions are governed by the Bankruptcy Code (the Code), 11 U.S.C. $\S \S 101-151326$ (as amended by Bankruptcy Amendments and Federal Judgeship Act of 1984, Pub. L. No. 98-353). The revised code has been published at 11 Bankr. CT. Dec. (CRR) (Issue 17, July 26, 1984) [hereinafter cited without cross-reference as 11 U.S.C. (1984 Revision) (CRR)]. A bankruptcy petition may be either voluntary or involuntary. A voluntary petition constitutes an order for relief. See 11 U.S.C. § 301 (1984 Revision) (CRR). Involuntary bankruptcy petitions become orders for relief only after court approval. See id. $\S 303$. For the purposes of this comment, all events occurring "after the filing of a bankruptcy petition" are presumed to occur after an order for relief has been entered by the bankruptcy court.

2 A "debtor" is a "person or municipality concerning which a case under this title has been commenced." 11 U.S.C. \& 101(12) (1984 Revision) (CRR). The Code defines a "person" as an "individual, partnership, . . . [or] . . . corporation," but the definition excludes governmental units. Id. § 101(33). For additional debtor qualifications, see id. § 109 .

3 The term "investor" includes any party with an ownership interest in the debtor's assets. Thus, the term encompasses all creditors, stockholders, and other parties holding contingent claims. This broad definition of ownership is necessary if bankruptcy is to be understood as a collective proceeding. See Baird \& Jackson, Corporate Reorganizations and the Treatment of Diverse Ownership Interests: A Comment on Adequate Protection of Secured Creditors in Bankruptcy, 51 U. CHr. L. RRv. 97, 100 n.15 (1984). The term "residual claimants" refers to those parties who have a claim on the debtor's assets but who take only after all other claims have been satisfied. Technically, this term includes only equityholders; when this comment addresses the duty of the bankruptcy trustee to maximize the estate for the benefit of "residual claimants," however, it refers to general creditors as well as stockholders (though the claims of general creditors technically have a higher priority than the claims of stockholders). This use is appropriate because trustee actions that have the effect of maximizing the return to general creditors necessarily have the additional effect of increasing the likelihood of a return to stockholders. See infra notes 109-13 and accompanying text. For the listing of priorities under the Bankruptcy Code, see 11 U.S.C \& 726 (1984 Revision) (CRR).

- The trustee is the court-appointed representative of the debtor's estate. See 11 U.S.C $\S \S 321-325$ (1984 Revision) (CRR).

- The commencement of a case under the Bankruptcy Code creates an "estate." Id. \$ 541(a). The debtor's estate is the pool of assets, which is administered by the trustee in bankruptcy and used to satisfy claims against the debtor. For a list of the types of property 
Code) ${ }^{8}$ confers broad power on the trustee to manage the debtor's estate; ${ }^{7}$ but because this delegation of power is necessarily general, the task of defining the precise contours of the trustee's power has devolved upon the courts. ${ }^{8}$ One question that courts have been called upon to answer concerns the trustee's power to waive the debtor's attorney-client privilege.

In recent litigation, trustees of both individual and corporate debtors have claimed the power to waive the debtor's attorney-client privilege in order to obtain information provided to the debtor's attorneys prior to the filing of the bankruptcy petition; they have argued that they need the privileged information to fulfill their duties to manage the debtor's business and to protect the value of the estate. ${ }^{10}$ The courts have failed to reach a consensus

that become part of the debtor's estate, see id. \& 541. See generally Jackson, Translating Assets and Liabilities to the Bankruptcy Forum, 14 J. Legal Stud. 73 (1985).

- Bankruptcy Reform Act of 1978, 11 U.S.C. $\$$ 101-151326 (1982) (amended by Bankruptcy Amendments and Federal Judgeship Act of 1984, Pub. L. No. 98-353). The Code was preceded by the Bankruptcy Act of 1898 (the Bankruptcy Act), ch. 541, 30 Stat. 544 (codified as amended at 11 U.S.C. $\$$ 1-1103 (1976)) (repealed 1978).

7 For example, the trustee may use, sell, or lease property of the debtor's estate in the ordinary course of the debtor's business without court approval and may do so outside the ordinary course of the debtor's business after notice and a hearing. 11 U.S.C. $\$ 363(b)$-(c)(1) (1984 Revision) (CRR). The trustee may also assume or reject executory contracts or unexpired leases, id. $\$ 365(a)$, and may operate the debtor's business during a reorganization, id. § 1108.

- See, e.g., Farmer v. Crocker Nat'l Bank (In re Swift Aire Lines), 30 Bankr. 490, 49596 (Bankr. 9th Cir. 1983) (holding that the trustee did not have the power under $\$ 365$ of the Code to draw on a letter of credit when he was precluded from obtaining conforming documents); In re Evelyn Byrnes, Inc., 32 Bankr. 825, 832 (Bankr. S.D.N.Y. 1983) (holding that the trustee had the power to assume and assign an unexpired lease when the lease required that the tenant maintain the "high standards of the building"); cf. NLRB v. Bildisco \& Bildisco, 104 S. Ct. 1188, 1194-95 (1984) (holding that the power of the debtor in possession to avoid executory contracts under $\$ 365$ of the Code included the porrer to avoid collective-bargaining agreements covered by the National Labor Relations Act and that unilateral modification of such contracts by the debtor in possession without prior court approval did not constitute an unfair labor practice).

- See, e.g., Commodity Futures Trading Comm'n v. Weintraub, 722 F.2d 338 (7th Cir. 1984) (holding that the trustee cannot waive a corporate debtor's attorney-client privilege), cert. granted, 53 U.S.L.W. 3310 (U.S. Oct. 30, 1984) (No. 84-261); Weissman v. Hassett (In re O.P.M. Leasing Servs., Inc.), 670 F.2d 383 (2d Cir. 1982) (holding that the trustee could waive a debtor corporation's attorney-client privilege when the corporate officers had resigned); Citibank v. Andros (In re Citibank), 666 F.2d 1192 (8th Cir. 1981) (holding that the trustee could waive a corporate debtor's attorney-client privilege); In re Smith, 24 Bankr. 3 (Bankr. S.D. Fla. 1982) (allowing the trustee to waive the debtor's attorney-client privilege when the debtor was an individual); In re Silvio De Lindegg Ocean Devs. of Am., Inc., 27 Bankr. 28 (Bankr. S.D. Fla. 1982) (holding that a trustee could not waive the debtor's attorney-client privilege when the debtor was an individual).

30 The trustee has the duty to maximize the estate for the benefit of all investors, whether they be creditors, equityholders, or tort claimants. See In re Washington Group, Inc., 476 F. Supp. 246, 250 (M.D.N.C. 1979) ("[T]he Trustee's duty is to act in the best 
on whether the trustee controls the debtor's attorney-client privilege. ${ }^{11}$ Even those courts that agree that the trustee should be allowed to waive the debtor's privilege have differed over the precise rationale for this conclusion. ${ }^{12}$ In addition, some courts have conflated the issue of whether the trustee can waive a corporation's

interests of the Debtor's estate.") (emphasis added), aff'd sub nom. Johnston v. Gilbert, 636 F.2d 1213 (4th Cir. 1980), cert. denied, 452 U.S. 940 (1982); DePinto v. United States, 407 F. Supp. 5, 7 (D. Ariz. 1976) ("[The trustee] has a duty . . . to realize the maximum profit on the bankruptcy estate."), aff'd, 585 F.2d 405 (9th Cir. 1978); B \& L Farms Co. v. United States, 238 F. Supp. 407, 410 (S.D.N.Y. 1963) ("[B]ankruptcy trustees do not represent creditors alone. They must protect the interests of the bankrupt . . . ."); In re Transatlantic \& Pac. Corp., 216 F. Supp. 546, 552 (S.D.N.Y. 1963) ("[The trustee's] actions must be compatible with the bankrupt's best interests as well as the interests of the bankrupt's creditors."); Baird \& Jackson, supra note 3, at 101-09. Some courts, in addressing the trustee's duty to maximize the assets of the debtor's estate, have described the trustee's duty as one of maximizing the assets for the benefit of creditors, without reference to the interests of investors generally. See, e.g., Commercial Credit Corp. v. Skutt, 341 F.2d 177, 181 (8th Cir. 1965) ("The trustee . . . has the duty to realize the maximum from the estate for distribution to the creditors."); In re Benny, 29 Bankr. 754, 760 (N.D. Cal. 1983) (similar); In re Crisp, 26 Bankr. 274, 275 (Bankr. W.D. Ky. 1982) ("The primary role of the trustee is to administer the estate . . . and to marshal for the benefit of the general creditors the maximum funds available for distribution."). These formulations result from the fact that the majority of bankruptcy estates are insufficient to satisfy the claims of the debtor's creditors and still have assets remaining for distribution to equityholders. In those cases, however, the unsecured creditors referred to by the courts are, in reality, the debtor's residual claimants. See supra note 3. The trustee's duty to maximize the assets of the estate for the benefit of investors requires the trustee to act in a manner most beneficial to equityholders when sufficient assets exist to satisfy the claims of the debtor's creditors and where the trustee's action will not pose an added risk to other investors.

11 For cases in which the trustee was allowed to waive a corporate debtor's attorneyclient privilege, see Weissman v. Hassett (In re O.P.M. Leasing Servs., Inc.), 670 F.2d 383 (2d Cir. 1982); Citibank v. Andros (In re Citibank), 666 F.2d 1192 (8th Cir. 1981); Turner v. Davis, Gillenwater \& Lynch (In re Investment Bankers), 30 Bankr. 883 (Bankr. D. Colo. 1983); In re National Trade Corp., 28 Bankr. 872 (Bankr. N.D. Ill. 1983); In re Silvio De Lindegg Ocean Devs. of Am., Inc., 27 Bankr. 28 (Bankr. S.D. Fla. 1982); In re Featherworks Corp., 25 Bankr. 634 (Bankr. E.D.N.Y. 1982); Gorman v. Martinez (In re Amjoe, Inc.), 11 Colrtar Bankr. CAs. (MB) 45 (Bankr. M.D. Fla. 1976). Cf. In re Boileau, 736 F.2d 503 (9th Cir. 1984) (allowing an examiner, who had been given the power of a trustee by stipulation of the parties, to waive the debtor's privilege); Weck v. District Court, 422 P.2d 46, 161 Colo. 384 (1967) (en banc) (allowing the trustee in bankruptcy to waive a corporate debtor's accountant-client privilege).

For cases holding that the trustee does not have the power to waive a corporate debtor's attorney-client privilege, see Commodity Futures Trading Comm'n v. Weintraub, 722 F.2d 338 (7th Cir. 1984), cert. granted, 53 U.S.L.W. 3310 (U.S. Oct. 30, 1984) (No. 84-261); Ross v. Popper, 9 Bankr. 485 (S.D.N.Y. 1980); In re Hy-Gain Elecs. Corp., 11 Bankr. 119 (D. Neb. 1978).

For cases discussing the trustee's power to waive the attorney-client privilege when the debtor is an individual, see Weintraub, 722 F.2d at 342-43 (dictum) (trustee may not waive individual debtor's attorney-client privilege); Silvio De Lindegg, 27 Bankr. at 28 (holding of the court) (same); In re Smith, 24 Bankr. 3 (Bankr. S.D. Fla. 1982) (trustee can waive individual debtor's attorney-client privilege).

1s See infra notes 21-45 and accompanying tert. 
attorney-client privilege with the issue of whether he can waive an individual's attorney-client privilege. ${ }^{13}$ These inconsistent approaches, and the differing outcomes to which they have led, result from a failure to analyze the issue with the primary goal of bankruptcy in mind: maximizing the debtor's estate for the benefit of all investors. The bankruptcy process achieves this goal by requiring the debtor's investors to participate in a collective proceeding. ${ }^{14}$ The nature of this collective proceeding provides the framework for defining the scope of the trustee's powers.

This comment examines the trustee's power to waive the attorney-client privilege in both the corporate and individual-debtor contexts, with special emphasis upon the former. After discussing typical situations in which the issue arises and examining the courts' treatment of the issue, the comment explicates the proper analytical framework in light of the United States Supreme Court's decision in Butner $v$. United States. ${ }^{15}$ The core of the Butner holding is that the touchstone of rights within bankruptcy is nonbankruptcy law. It is necessary that some changes in the debtor's situation occur upon the filing of a bankruptcy petition; the appointment of a trustee is an example of such a change. Nevertheless, the proper way to gauge the effect of those changes on the rights of parties involved in a bankruptcy proceeding is to analogize the change to a similar event in nonbankruptcy law and then to use this analogy to establish the substantive rights of the parties in bankruptcy. With this analytical framework in mind, the comment explores the nature of the attorney-client privilege outside of bankruptcy. The comment then argues that, in the case of a corporate debtor, the appointment of a trustee most closely

13 See Commodity Futures Trading Comm'n v. Weintraub, 722 F.2d 338, 342-43 (7th Cir. 1984) (if a trustee is given control of the attorney-client privilege of a corporate debtor, then a trustee must also be given control of the debtor's attorney-client privilege in the case of an individual debtor), cert. granted, 53 U.S.L.W. 3310 (U.S. Oct. 30, 1984) (No. 84-261); In re Smith, 24 Bankr. 3 (Bankr. S.D. Fla. 1982) (citing cases that allow waiver of the privilege when the debtor is a corporation as precedent for allowing waiver when the debtor is an individual). But see In re Silvio De Lindegg Ocean Devs. of Am., Inc., 27 Bankr. 28, 28 (Bankr. S.D. Fla. 1982) ("[T]here is no reason why the trustee cannot waive a corporate debtor's attorney-client privilege. There is every reason ... why the trustee cannot waive an individual debtor's attorney-client privilege.").

14 For a discussion of bankruptcy as a collective proceeding, see Jackson, Bankruptcy, Non-Bankruptcy Entitlements, and the Creditors' Bargain, 91 YALE L.J. 857 (1982). Professor Jackson argues that the return to all investors is maximized in bankruptcy because the bankruptcy mechanism causes the assets of the estate to be deployed in the same manner that they would be deployed by a sole owner of the assets. Id. at 859-71; see also Baird \& Jackson, supra note 3, at 101-09.

15 440 U.S. 48 (1979). 
resembles a change in management and that, in the case of an individual debtor, it resembles a sale of the debtor's assets. The comment concludes that, under this analysis, the trustee has the power to waive the debtor's attorney-client privilege only when the debtor is a corporation.

\section{The Problem of the Attorney-Client Privilege IN BANKRUPTCY}

\section{A. The Waiver Issue}

Before examining the trustee's power to waive a debtor's attorney-client privilege, it is necessary to examine the contexts in which the issue usually arises. While the situations may appear similar whether a corporate or individual debtor is involved, the considerations involved in the two cases vary considerably.

To illustrate the issue in the case of a corporate debtor, assume that $A, B$, and $C$ are the only directors of Debtor Corporation, a manufacturer of sporting goods. Throughout its existence, Debtor Corporation has employed Law Firm as its corporate counsel. During their tenure as directors, $A, B$, and $C$ have met frequently with Law Firm to discuss the legal ramifications of the board's decisions. In order to assist Law Firm in giving its advice, Debtor Corporation has communicated information concerning its financial condition to Law Firm. ${ }^{16}$ By March 1, retail sales of sporting goods have declined sharply, and Debtor Corporation has begun to experience cash-flow problems. On April 1, Debtor Corporation realizes that it cannot meet its financial obligations to a local bank, and the bank threatens to foreclose on the goods in Debtor Corporation's warehouse. Debtor Corporation files a voluntary petition in bankruptcy in chapter $7,{ }^{17}$ and on April 10, Trustee

16 For the purposes of this comment, the attorney-client privilege is assumed to cover all relevant discussions between the debtor and its attorneys. The requirements for the privilege have been summarized as follows:

(1) Where legal advice of any kind is sought (2) from a professional legal adviser in his capacity as such, (3) the communications relating to that purpose, (4) made in confidence (5) by the client, (6) are at his instance permanently protected (7) from disclosure by himself or by the legal adviser, (8) except the protection be waived.

8 J. Wigmore, Evidence $\$ 2292$, at 554 (J. McNaughton rev. ed. 1961); see also United States v. United Shoe Mach. Corp., 89 F. Supp. 357, 358-59 (D. Mass. 1950) (setting forth similar requirements).

17 Corporate liquidations and corporate reorganizations in bankruptcy are governed by separate chapters of the Code. Compare 11 U.S.C. ch. 7 (1984 Revision) (CRR) (liquidations) with id. ch. 11 (reorganizations). For the purposes of this comment, it is immaterial whether the debtor is involved in a liquidation or a reorganization. The manner in which the debtor's assets are to be deployed and the allocation of rights among the parties to a bank- 
is appointed by the bankruptcy court to handle the affairs of Debtor Corporation.

On May 1, Trustee authorizes an audit of Debtor Corporation. The audit reveals that several million dollars of receivables that Debtor Corporation's financial records indicate were collected cannot be traced to any of Debtor Corporation's bank accounts. During this period, the Internal Revenue Service notices some inconsistencies in the individual tax returns of the directors, and the IRS begins a comprehensive investigation of the financial transactions of $A, B$, and $C$. In the course of its investigation, the IRS asks Trustee for Debtor Corporation's internal audits. Trustee cannot find any of Debtor Corporation's internal audits. In order to assist its investigation, the IRS requests that Trustee waive Debtor Corporation's attorney-client privilege as to the financial information communicated to Law Firm. Trustee also wishes to obtain this information in order to decide whether to pursue a civil action against the directors for breach of their fiduciary duties. ${ }^{18}$ Trustee asks Law Firm for the financial information, but Law Firm declines on the ground that Debtor Corporation's attorney-client privilege prevents such disclosure. Trustee brings a motion in the bankruptcy court to compel disclosure by Law Firm, and $A, B$, and $C$ intervene seeking to assert the attorney-client privilege in their role as Debtor Corporation's directors.

A similar situation can occur with an individual debtor. To illustrate this, assume that Debtor, an individual, owns and operates a small sporting goods store as a proprietorship. Debtor regularly communicates to his counsel, Attorney, information concerning his financial condition so that Attorney can give advice to Debtor about the legal ramifications of certain transactions. On March 1 , Debtor's business begins to decline and on April 1, Debtor files for bankruptcy. ${ }^{19}$ On April 10, Trustee is appointed to manage the as-

ruptcy proceeding are distinct issues; because it is in the best interest of all the investors to maximize the amount available for distribution, the determination of each of these questions should be made independently of the other. See Baird \& Jackson, supra note 3, at 101-09.

In chapter 7 proceedings, trustees are elected by the debtor's creditors. See 11 U.S.C. $\$ 702$ (1984 Revision) (CRR). In chapter 11 proceedings, a trustee may be appointed when such appointment is in the best interest of the estate. See id. $\$ 1104(a)$. If a trustee is not appointed, the current management continues to manage the debtor in the capacity of a "debtor in possession," enjoying the same rights, powers, and duties as a trustee. See id. \&1107.

13 For a collection of cases and articles on the subject of fiduciary duties and suits for breach thereof, see DeTLBy VAgts, Basic Corporation LAw 207-98 (2d ed. 1979).

1* Individual bankruptcies are governed by 11 U.S.C. ch. 13 (1984 Revision) (CRR). 
sets of Debtor..$^{20}$ On April 15, the Internal Revenue Service begins an audit of Debtor's tax return, and on May 1, the IRS requests Debtor's receipts. Debtor refuses to hand them over. The IRS then asks Attorney to deliver any information he has regarding the operation of Debtor's store. Attorney refuses to produce the requested information on the ground that doing so would violate Debtor's attorney-client privilege. The IRS then asks Trustee to waive Debtor's attorney-client privilege so that it can gain access to the information it needs. Trustee, who would like to see this information himself so he can trace all of Debtor's assets, petitions the bankruptcy court for permission to waive the attorney-client privilege. Debtor opposes this motion.

\section{B. The Case Law}

At least three courts of appeals and a number of lower federal courts have recently considered whether a trustee in bankruptcy has the power to assert or waive a debtor's attorney-client privilege with respect to communications preceding the filing of a bankruptcy petition. ${ }^{21}$ A majority of these courts have allowed the trustee to control the privilege when the debtor is a corporation. The language and legislative history of the Code give no direct guidance in resolving this issue, ${ }^{22}$ however, and the courts have used differing rationales to arrive at this conclusion.

Some courts have justified their finding that the trustee controls the corporate debtor's attorney-client privilege on the ground that the privilege is property of the estate, which passes to the trustee along with the other assets of the debtor. ${ }^{23}$ Other courts $\S 1302$.

${ }^{20}$ In individual bankruptcies, trustees are always appointed by the court. See id.

21 See supra notes 9-13 and accompanying text.

22 Section 542 permits a court to require any person holding recorded information relating to the debtor to turn over such information to the trustee, but only "[s]ubject to any applicable privilege." 11 U.S.C. \& 542(e) (1984 Revision) (CRR). The legislative history merely states that "[t]he extent to which the attorney-client privilege is valid against the trustee is unclear under current law and is left to be determined by the courts on a case by case basis." 124 Cong. REc. 32,400 (1978).

${ }^{23}$ See, e.g., Citibank v. Andros (In re Citibank), 666 F.2d 1192, 1195 (8th Cir. 1981); cf. In re Boileau, 736 F.2d 503 (9th Cir. 1984) (relying on the Citibank decision in allowing an examiner who had been given the power of a trustee by stipulation of the parties to waive the debtor's privilege). But see In re Hy-Gain Elecs., Inc., 11 Bankr. 119 (D. Neb. 1978) (holding that the right to waive a corporation's attorney-client privilege was not a form of property that became part of the bankrupt's estate under the Bankruptcy Act); cf. In re O.P.M. Leasing Servs., Inc., 13 Bankr. 54, 61 (Bankr. S.D.N.Y.) (holding that the waiver right passes to the bankruptcy trustee under the Code, but conceding that the court in $H y$ Gain "may be" correct in stating that "the privilege is itself a privilege and not a form of 
have based their conclusion on the fact that the trustee must have the power to waive the privilege in order to fulfill his duties as representative of the estate. ${ }^{24}$ Moreover, a number of courts have relied on both these rationales in allowing the trustee to waive a corporate debtor's attorney-client privilege. ${ }^{25}$ Finally, one court has relied on both rationales in allowing the trustee to waive an individual debtor's attorney-client privilege. ${ }^{28}$ A small number of courts, however, have refused to recognize any right on the part of the trustee to waive or assert the debtor's attorney-client privilege. ${ }^{27}$ Close examination reveals that each of the rationales offered

property" ") (quoting In re Hy-Gain Elecs., Inc., 11 Bankr. 119, 120 (D. Neb. 1978)), aff'd, 13 Bankr. 64 (S.D.N.Y. 1981), aff'd sub nom. Weissman v. Hassett (In re O.P.M. Leasing Servs., Inc.), 670 F.2d 383 (2d Cir. 1982); In re McCourt, 12 Bankr. 587 (Bankr. S.D.N.Y. 1981) (holding that a surviving spouse's right of election is a personal right and is not $\$ 541$ property).

14 See, e.g., In re O.P.M. Leasing Servs., Inc., 13 Bankr. 54 (Bankr. S.D.N.Y.), aff'd, 13 Bankr. 64 (S.D.N.Y. 1981), aff'd sub nom. Weissman v. Hassett (In re O.P.M. Leasing Servs., Inc.), 670 F.2d 383 (2d Cir. 1982). In granting the trustee the power to waive the corporate debtor's attorney-client privilege, the bankruptcy court in O.P.M. Leasing relied in part on the fact that the proceeding was in chapter 11 and in part on the fact that the debtor had consented to the appointment of a trustee. See 13 Bankr. at 62. The court did not explain, however, how these arguments support the proposition that the trustee possesses the waiver right, and these arguments are in fact insufficient to support the court's conclusion.

The court's first argument creates an unprincipled distinction between chapter 7 cases, where a trustee is required, see 11 U.S.C. $\$ 701$ (1984 Revision) (CRR), and chapter 11 cases, where a trustee may not be required, see $\$ 1104$. In chapter 11 cases, the estate may instead be administered by a debtor in possession with powers virtually identical to those of the trustee. See id. § 1107. Furthermore, there are other reasons why it is not mandatory that a trustee be appointed in a chapter 11 case. For example, not requiring a trustee allows "debtors, creditors, and equityholders greater flexibility in handling the affairs of an insolvent debtor, permitting the court to tailor the remedy to the case." H.R. REP. No. 595, 95th Cong., 1st Sess. 403 (1977). Consent by the debtor to the appointment of a trustee may thus have little or nothing to do with the notion that the trustee serves as a representative of the debtor. The court's argument based on the debtor's consent to the appointment of the trustee is also unsound because there is no basis for permitting a corporate debtor's decision to have a trustee appointed to add to the trustee's powers when the trustee's powers under the statute are equivalent to those that the debtor in possession would have in the absence of such an appointment. See 11 U.S.C. § 1107 (1984 Revision) (CRR). Moreover, creditors may have enough leverage to force a corporation's consent to the appointment of a trustee. What may appear to be voluntary consent may thus not be voluntary at all. See D. BAIRD \& T. Jackson, Cases, Problems and Matzrials on Bankruptcy ch. 2 (forthcoming). Thus, management's approval of a trustee's appointment is immaterial to the determination of whether it is the trustee or the corporate debtor's directors that should be deemed representative of the debtor for the purposes of waiver.

28 See Turner v. Davis, Gillenwater \& Lynch (In re Investment Bankers, Inc.), 30 Bankr. 883 (Bankr. D. Colo. 1983); In re National Trade Corp., 28 Bankr. 872 (Bankr. N.D. IIl. 1983); In re Featherworks Corp., 25 Bankr. 634 (Bankr. E.D.N.Y. 1982).

${ }^{26}$ In re Smith, 24 Bankr. 3, 5 (Bankr. S.D. Fla. 1982) (citing cases employing both rationales).

${ }^{27}$ See Commodity Futures Trading Comm'n v. Weintraub, 722 F.2d 338 (7th Cir. 
by the courts is either inconsistent with the language and structure of the Code or unpersuasive.

The assertion that the debtor's attorney-client privilege passes to the trustee as property of the estate is inconsistent with the language of the Code. Section 541 defines property of the estate as "all legal and equitable interests of the debtor in property as of the commencement of the case," ${ }^{\prime 28}$ and section 542 provides that, with certain exceptions, such property shall be turned over to the trustee. ${ }^{2 \theta}$ Yet the right to assert or waive the attorney-client privilege is not a right that can be bought, sold, or levied upon by creditors, ${ }^{30}$ and none of the cases offering this property argument discusses the nature of the privilege or the propriety of characterizing it as property within the meaning of section 541. Because the attorney-client privilege cannot be considered "property" within the definition of that term in section 541 , it cannot be treated as something that is turned over to the trustee under the requirements of section 542 .

It is also unpersuasive to justify vesting the power to waive the privilege in the trustee based on the characterization of the trustee as the representative of the estate. Courts employing this rationale essentially make the following argument. The attorney-client privilege exists "to protect and foster the interests of actual litigants,"31 and the trustee is the party representing the property interests of the debtor in litigation; if the right to waive the privilege were vested in the officers or directors, rather than in the trustee, the privilege would fail to benefit the litigating party it was designed to protect; ${ }^{32}$ therefore, the trustee should have the power to exercise the privilege as he wishes. This argument suffers from two flaws. First, it assumes that the privilege is closely linked to the property rights belonging to the estate, that those rights pass to the trustee, and that, when such rights pass to the trustee, the privilege follows. But under the Code, there is no transfer of property to the trustee. The trustee is only "the representative of the

1984), cert. granted, 53 U.S.L.W. 3310 (U.S. Oct. 30, 1984) (No. 84-261); Ross v. Popper, 9 Bankr. 485 (S.D.N.Y. 1980); In re Hy-Gain Elecs. Corp., 11 Bankr. 119 (D. Neb. 1978).

${ }^{28} 11$ U.S.C. $\S 541(\mathrm{a})(1)$ (1984 Revision) (CRR).

20 Id. \$ 542.

so Cf. Chicago Bd. of Trade v. Johnson, 264 U.S. 1, 11 (1924) (holding that a seat on the Chicago Board of Trade was property of the estate in part because the member "can transfer it or sell it subject to a right of his creditors to prevent his transfer or sale till he settles with them, - a right in some respects similar to the typical lien of the common law . . . .").

s1 Gorman v. Martinez (In re Amjoe, Inc.), 11 ColuIER Bankr. CAs. (MB) 45, 49 (Bankr. M.D. Fla. 1976).

ss Id. 
estate"; 38 no change in ownership is contemplated. ${ }^{34}$ Thus, this argument does not explain why the trustee, rather than the corporate debtor's directors or an individual debtor, should have the power to waive the privilege.

Second, by focusing attention on the question of which party has control of the debtor's property, this argument fails to distinguish between individual and corporate debtors. As this comment will show, ${ }^{35}$ the concerns involved in assessing the issue in the context of an individual debtor are so fundamentally different from those involved with a corporate debtor that the issue of whether the trustee can waive the debtor's attorney-client privilege must be addressed separately in each situation.

The most important case addressing the issue of the power of a trustee in bankruptcy to control the attorney-client privilege of a corporate debtor is Commodity Futures Trading Commission $v$. Weintraub. ${ }^{36}$ In Weintraub, the Seventh Circuit held that the corporate directors, and not the trustee, control the debtor's attorneyclient privilege. This decision offers the most thorough argument to date for denying the trustee the power to waive the privilege. The court gave four justifications for this conclusion. First, the court concluded that, because the trustee does not "succeed to the positions of the officers and directors of the corporation," the granting of broad powers to the trustee under the Code does not also vest control over the privilege in the trustee. ${ }^{37}$ The corporation still exists after a petition in bankruptcy is filed, and "is capable of performing numerous functions." 38 Thus, while the trustee may gain control over the corporate debtor's property, he does not also gain absolute control over its legal rights. Second, assuming that the trustee could not waive an individual's attorney-client privilege, the court asserted that to allow the trustee to waive the privi-

33 11 U.S.C. \& 323(a) (1984 Revision) (CRR).

36 A limited right of waiver may accompany the transfer of an interest in property, but the right to waive is transferred only to the extent necessary to ensure the realization of the transfer of the underlying property interest. $8 \mathrm{~J}$. WiGMORE, supra note $16, \S 2329$, at 639; cf. Hoffman, The Attorney-Client Privilege in Proceedings Under the Bankruptcy Act of 1898 and the Bankruptcy Reform Act of 1978, 53 AM. BANkR. L.J. 231, 248 (1979) ("The signifcant difference between ownership and representation would appear to be crucial to the ability to equate a trustee with an assignee."). Thus, even if the debtor's property is considered to have been transferred to the trustee, the privilege cannot be said to have followed, because it is not necessary to perfect the transfer of any property in the estate.

25 See infra notes 116-26 and accompanying text.

se 722 F.2d 338 (7th Cir. 1984), cert. granted, 53 U.S.L.W. 3310 (U.S. Oct. 30, 1984) (No. 84-261).

3722 F.2d at 342 .

s. Id. 
lege in the case of a corporation would result in an unequal treatment of individual and corporate debtors. ${ }^{39}$ Third, the court reasoned that allowing the trustee to waive the attorney-client privilege would amount to "discriminat[ion] against the corporate debtor on the basis of economic status."40 The court implied that it would be unfair to transfer control of a corporation's attorney-client privilege merely because its status had changed from that of a solvent corporation to that of an insolvent one.11 Finally, the court concluded that allowing a debtor's attorney-client privilege to be waived by the trustee would have a chilling effect on attorney-client communications, thus defeating the very purpose the privilege seeks to further. ${ }^{2}$

The Seventh Circuit properly began its analysis by examining the powers of the trustee. ${ }^{48}$ Nevertheless, the court did not explain why an examination of the relationship between the powers vested in the trustee and those retained by the corporate management is relevant, and it did not carry the analysis far enough. The remaining three justifications given by the court are also unsatisfactory because they fail to take into account the unique situation of a trustee in bankruptcy, the underlying purposes of the bankruptcy process, and the considerations that justify disparate treatment of corporate and individual debtors.

The issue of whether the debtor or the trustee controls the attorney-client privilege in bankruptcy is only one of a number of issues that the Code fails to address explicitly. ${ }^{44}$ As in all cases

s9 Id. at 342-43.

40 Id. at 343.

41 This reasoning assumes that once the privilege is vested in the trustee of a corporate debtor, the trustee will use the privilege in a manner that is contrary to the best interest of the corporation. This comment will show, infra notes 107-14 and accompanying text, that this assumption is incorrect.

422 F.2d at 343.

4s For a justification of this analysis, see infra notes 46-62 and accompanying text.

4t The Code's legislative history offers little aid in the resolution of the general issue. The drafters of section 542(e), which deals with the turnover of financial information to the trustee, stated that "[the turnover] duty is subject to any applicable claim of privilege, such as the attorney-client privilege." H.R. REP. No. 989, 95th Cong., 1st Sess. 369 (1977); see also S. REP. No. 989, 95th Cong., 2d Sess. 84 (1978). Other statements made during the discussion of section 542(e), however, explicitly indicate that this issue was left open. See supra note 22 .

One could argue that because there is no specific grant of authority in the Code, the trustee does not have the power to waive the attorney-client privilege. But one could also argue that, in the absence of a congressional expression of intent, a court must follow the nonbankruptcy rule and allow the trustee, as current management, to waive the privilege. The discussion in the legislative history indicates that an approach that denies the trustee control of the corporate debtor's privilege based solely upon the absence of a specific grant 
where the Code is silent on an issue and where the courts are expected to deal with the problem on a "case by case basis,"4s the issue should be resolved with the help of a general theoretical framework of bankruptcy in mind. This is especially important where the legislative history is almost completely silent on the issue, and one has only the general purposes behind the bankruptcy process to rely on. Before returning to a detailed critique of the Weintraub decision, the following sections of this comment develop the appropriate framework for resolving issues that the Code does not address.

\section{Determining the Scope of Rights in Bankruptcy}

Although the Supreme Court has never addressed the issue of which party controls a debtor's attorney-client privilege, it has answered the more general question of how rights should be distributed in bankruptcy when federal bankruptcy law fails to provide a specific solution. In Butner $v$. United States, ${ }^{46}$ the Court was faced with the issue of how the bankruptcy court should distribute rents that had accrued and been paid to the debtor's estate during the

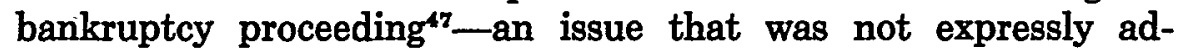
dressed by any provision of the Bankruptcy Act. ${ }^{48}$ More generally, the Court was called upon to decide whether state law (i.e., the rule that would apply outside of bankruptcy) or a federal rule of equity (i.e., a rule to be applied only in bankruptcy) should govern the determination. In a unanimous opinion, the Court held: "Property interests are created and defined by state law. . . . [T] no reason why such interests should be analyzed differently simply because an interested party is involved in a bankruptcy proceeding."49 The Court stressed that state (i.e., nonbankruptcy) law would always apply in such situations, "[u]nless some federal interest requires a different result."

In arriving at its conclusion, the Court emphasized the conse-

of authority in the Code is overly formalistic and was not intended by the Code's drafters. If anything, the legislative history makes it clear that Congress was not going to clarify the issue one way or the other and that the courts would have to rely on broader principles to resolve it. As is the case with any ambiguous delegation of power to the trustee, defining the specific bounds of the trustee's powers is a proper task for the courts.

\footnotetext{
is See supra note 22.

440 U.S. 48 (1979).

4 Id. at $49-51$.

1" Id. at 54 .

4. Id. at 55 .

$\omega$ Id.
} 
quences of a contrary holding:"s1 "Uniform treatment of property interests by both state and federal courts within a State serves to reduce uncertainty, to discourage forum shopping, and to prevent a party from receiving 'a windfall merely by reason of the happenstance of bankruptcy." "52 These considerations all stem from a concern about the incentives created by the bankruptcy process whenever the rules within bankruptcy differ from those outside of bankruptcy. In the particular situation facing the Court in Butner, no federal interest would have been served by applying a rule other than the one provided by state law; the only effect would have been to give parties an incentive to obtain the jurisdiction of a bankruptcy court to resolve an issue more favorably than would be possible under state law. ${ }^{\text {s }}$

Butner thus creates a presumption that rights inside of bankruptcy are coextensive with rights outside of bankruptcy. If bankruptcy were to change the substantive rights of the parties involved in a proceeding, then certain parties might receive a windfall through the "happenstance of bankruptcy." As the Court indicated, such a result would be justified only if a "federal interanalysis:

s1 The Court's decision also seemed to rest in part on a federal-law preemption

"The Federal Constitution, Article $1, \S 8$, gives Congress the power to establish uniform laws on the subject of bankruptcy throughout the United States. In view of this grant of authority to the Congress it has been settled from an early date that state laws to the extent that they conflict with the laws of Congress, enacted under its constitutional authority, on the subject of bankruptcies are suspended. While this is true, state laws are thus suspended only to the extent of actual conflict with the system provided by the Bankruptcy Act of Congress."

440 U.S. at 54 n.9 (quoting Stellwagen v. Clum, 245 U.S. 605, 613 (1918)) (citations omitted). Under this approach, state law always applies, even in bankruptcy, unless there is a conflicting, and thus overriding, federal interest in providing a uniform rule in a particular situation. This form of analysis alone, however, does not fully resolve the problem of the determination of rights where the Code is silent. For example, the Court's opinion does not expressly state that the overriding "federal interest" must be determined by Congress through the bankruptcy statute, and it seems to leave room for the courts to apply their own uniform federal rules where a "federal interest" is compelling. The Court's opinion seems, however, to indicate that such questions can only be addressed by looking at the purposes to be served by the bankruptcy system and the way in which the incentives created by a particular rule relate to those purposes.

${ }^{82}$ Id. at 55 (citing Lewis v. Manufacturers Nat'l Bank, 364 U.S. 603, 609 (1961)).

6s In furtherance of the goal of ensuring that rights within bankruptcy are the same as those outside of bankruptcy, the Court placed on the bankruptcy court an affirmative duty to protect the state law rights of parties: "[T] he federal bankruptcy court should take whatever steps are necessary to ensure that the mortgagee is afforded in federal bankruptcy court the same protection he would have under state law if no bankruptcy had ensued." 440 U.S. at 56. This duty even requires the bankruptcy court to assure that any delay in granting a remedy to which a party is entitled under state law be no greater than that which would be necessary in a state court. Id. at 56-57. 
est" were involved. The definition of what constitutes a sufficient federal interest can only be determined with reference to the underlying purpose of the bankruptcy process: preserving and enhancing the assets of the debtor.

To illustrate a situation in which an unjustified windfall might arise from a change in rights under bankruptcy, assume that under state law an individual cannot sell his seat on a board of trade without first paying off his debts to the board and its members. If bankruptcy law did not recognize this state-law limitation on the disposition of the seat, general creditors (who, outside of bankruptcy, could only receive the proceeds from the sale of the seat after the board had been paid in full) would share the proceeds from the sale of a debtor's seat proportionally with the board. ${ }^{\text {st }}$ Thus, if a bankruptcy trustee could sell the seat without first paying off the debts to the board, nonmember creditors would have an incentive to force the debtor into bankruptcy in order to take advantage of the favorable change in their substantive rights. Conversely, creditors who were members of the board would have an incentive to keep the debtor out of bankruptcy until the seat could be sold, in order to preserve their right to be paid in full. These incentives might cause the decision to enter into or stay out of bankruptcy to be made without regard to the appropriateness of using the bankruptcy process.

The Butner analysis of the determination of property rights within bankruptcy applies with equal force to the determination of nonproperty rights, including control of the attorney-client privilege. This is shown by the fact that a similar kind of unjustified windfall might arise if control of the attorney-client privilege did not depend upon nonbankruptcy law. Returning to the example used earlier, ${ }^{\mathrm{ss}}$ assume that, outside of bankruptcy, directors $A, B$, and $C$ are, because of an impending corporate takeover, about to lose the right to assert Debtor Corporation's attorney-client privilege. If bankruptcy law did not mirror the way in which nonbankruptcy law distributes this right, $A, B$, and $C$ could file a petition in bankruptcy on behalf of Debtor Corporation merely to ensure that they will not lose control over Debtor's attorney-client privilege. No bankruptcy purpose is served by granting $A, B$, and $C$ this

w These facts are based loosely upon those of Chicago Bd. of Trade v. Johnson, 264 U.S. 1 (1924), where the Court held that the bankruptcy court must enforce the Board's "lien" on the seat and require that the Board be paid in full before any proceeds could go to the debtor's estate. 264 U.S. at 14-15.

See infra note 69 and accompanying text. 
windfall. ${ }^{.6}$ Under this analysis, it is irrelevant that Butner dealt with state-created rights while the attorney-client privilege in bankruptcy is governed by federal law. The crux of the Butner analysis is that one party should not obtain a windfall due to the mere "happenstance of bankruptcy." The appropriate concern is with the effect of altering rights in bankruptcy, rather than with the source of the rights.

This application of Butner also comports with the "creditors' bargain" model of bankruptcy, which views bankruptcy law as the set of rules creditors would contract for ex ante if such negotiations were possible. ${ }^{57}$ Because creditors would contract for a proceeding that recognizes all nonbankruptcy entitlements while preventing piecemeal liquidation of the debtor in state-court pro-

56 The same skewed incentive that is created by a change in the way property rights are treated in bankruptcy thus results when other, nonproperty rights are altered within the bankruptcy forum. Assume, for example, that the directors of Debtor Corporation know that the corporation is financially troubled and susceptible to a takeover bid and that the directors fear that the disclosure of privileged information could result in personal liability, either criminal or civil. Outside of bankruptcy, if Debtor Corporation is taken over by Parent Corporation and if Parent Corporation installs $X, Y$, and $Z$ as directors of Debtor Corporation, $X, Y$, and $Z$ would then have the power to waive the privilege for the benefit of Debtor Corporation's owners. See infra note 69 and accompanying text. If the trustee in bankruptcy could not waive the privilege on behalf of the corporation, the current directors would have an incentive to file a bankruptcy petition. This incentive for $A, B$, and $C$ to enter Debtor Corporation into bankruptcy would arise not because the bankruptcy forum results in an allocation of the Debtor Corporation's assets more beneficial to the investors, but because the bankruptcy forum would offer them a favorable change in their substantive rights. If, inside bankruptcy, Trustee has the power to waive the privilege, then $A, B$, and $C$ have nothing to gain by filing a petition in bankruptcy because, whether a petition is filed or not, the current management of Debtor Corporation, not $A, B$, and $C$, will possess the waiver right.

The creditors of Debtor Corporation would also have a skewed incentive if the right to waive the attorney-client privilege within bankruptcy were determined differently than it is outside of bankruptcy. In deciding whether to force Debtor Corporation into bankruptcy, they would have to weigh the benefits of a collective proceeding against the probability that information concerning a possible breach of duty on the part of Debtor Corporation's directors would be unavailable. Such information, if obtained, could be used to recover damages against the directors and thus increase Debtor Corporation's estate for the benefit of all creditors. Rather than pursue a possibly more beneficial bankruptcy proceeding, the creditors might wait, pursue their state-law remedies, and hope that either the corporation would be acquired or new management would be elected by the shareholders and the information would be revealed.

Such skewed incentives occur whenever there is a change in the substantive rights of parties involved in a bankruptcy proceeding and the change is made for a purpose other than to facilitate a collective proceeding. See Baird \& Jackson, supra note 3, at 97-109; Eisenberg, Bankruptcy Law in Perspective, 28 UCLA L. Rev. 953, 953-59 (1981); Jackson, supra note 14, at 857-71; Jackson, supra note 5, at 73-77.

s7 See generally Baird \& Jackson, supra note 3, at 97-109; Jackson, supra note 14, at 859-71. 
ceedings, bankruptcy is viewed merely as a procedural forum for sorting out nonbankruptcy entitlements. ${ }^{58}$ These entitlements should be altered only when there is a bankruptcy reason for doing so. ${ }^{50}$ Thus, under this normative theory of bankruptcy, the attorney-client privilege should be allocated according to nonbankruptcy law, unless some bankruptcy reason exists for not doing so.

This normative view of bankruptcy recognizes that some changes must occur within bankruptcy in order to facilitate the collective proceeding. The appointment of a trustee is an example of such a change. Because the trustee exists only within bankruptcy, one cannot merely assert that bankruptcy rights should mirror nonbankruptcy rights in defining the powers of the trustee. Here again, however, the Butner analysis provides guidance. The trustee is given certain powers and duties that would otherwise be exercised by others outside of bankruptcy, ${ }^{60}$ as well as certain powers and duties that are possessed only by trustees in bankruptcy. ${ }^{61}$ In order to determine whether a power normally held by others should be exercised by the trustee, one must compare the role of the trustee with the role of those who would exercise the power outside of bankruptcy. If the role of the trustee is sufficiently analogous to that of another party who exercises a certain power outside of bankruptcy, then the trustee should have that power within bankruptcy. Under this approach, no party could gain a windfall in bankruptcy from a change in substantive rights.

The proper framework for analyzing the power of the trustee with respect to the attorney-client privilege is this: first, the scope of the attorney-client privilege outside of bankruptcy must be defined; next, the appointment of a trustee must be analogized to a similar transfer of power outside of bankruptcy; finally, the effect this change would have on the attorney-client privilege outside of bankruptcy must be determined. Under this framework, the role of the trustee in bankruptcy is most closely analogous, in the case of a corporate debtor, to that of new management, and thus the trustee should possess the same power to waive the attorney-client privilege that new management would have outside of

\footnotetext{
se See Baird \& Jackson, supra note 3, at 97-109; Eisenberg, supra note 56, at 956-59; Jackson, supra note 14, at 859-71.

See sources cited supra note 58.

co See, e.g., 11 U.S.C. $\$ 363(\mathrm{c})(1)$ (1984 Revision) (CRR) (allowing the trustee to use property of the debtor's estate in the ordinary course of business); id. $\$ 364$ (allowing the trustee to incur unsecured debt in the operation of the debtor's business).

a See, e.g., id. \&547 (allowing the trustee to recover certain asset transfers as voidable preferences); id. $\S 544$ (allowing the trustee to avoid unperfected security interests).
} 
bankruptcy. ${ }^{62}$

\section{The Purpose and Scope of the Attorney-Cluent Privilege in Nonbankruptcy Law}

Of all the privileges for communications developed at common law, the attorney-client privilege is the oldest. ${ }^{63}$ The purpose of the privilege is to assure that clients' communications with their lawyers will not be chilled by the prospect that the lawyer may later be forced to divulge sensitive information to others. ${ }^{64}$ Lawyers will thus be more fully informed in representing the interests of their clients and will therefore be able to give sounder legal advice and advocate their clients' cases more effectively: the privilege exists to "encourage full and frank communication between attorneys and their clients and thereby promote broader public interests in the observance of law and administration of justice." client privilege applies to litigation in the federal courts ${ }^{86}$ and attaches to corporations as well as to individuals. ${ }^{67}$ Because the privilege by its very nature serves to prevent disclosure, however, courts have restricted its scope. ${ }^{68}$ An example of such a limitation is the rule that the directors of a corporation who divulge information to the corporation's attorney may not control the privilege as to that communication indefinitely: a new board of directors is free to waive the privilege. ${ }^{60}$

\footnotetext{
6s See infra notes 81-113 and accompanying text.

63 Upjohn Co. v. United States, 449 U.S. 383, 389 (1980).

of Fisher v. United States, 425 U.S. 391, 403 (1976); 8 J. WIGMoRE, supra note 16, $\S 2291$.

os Upjohn Co. v. United States, 449 U.S. 383, 389 (1980); see also Trammel v. United States, 445 U.S. 40, 51 (1980).

os Fed. R. EvID. 501; Upjohn Co, v. United States, 449 U.S. 383, 389 (1980).

${ }^{67}$ Upjohn Co. v. United States, 449 U.S. 383, 389-90 (1980); see also United States v. Louisville \& N.R.R., 236 U.S. 318, 336 (1915).

os See, e.g., Baird v. Koerner, 279 F.2d 623, 631-32 (9th Cir. 1960) ("[The attorneyclient privilege] is to be strictly limited to the purposes for which it exists."); In re Grand Jury Proceedings, 434 F. Supp. 648, 649 (E.D. Mich. 1977) ("[Privileges] are developed and expanded only to accomodate needs that can be narrowly defined and, when so defined, require protection to a greater degree than does the need for testimony."), aff'd, 570 F.2d 562 (6th Cir. 1978); In re Grand Jury Subpoena, 391 F. Supp. 1029, 1033 (S.D.N.Y. 1975) ("IT]he privilege has been confined to a narrow and limited enclave. . . [ [T]he privilege is strictly limited in purpose and effect.").

99 See, e.g., Weissman v. Hassett (In re O.P.M. Leasing Servs., Inc.), 670 F.2d 383, 386 (2d Cir. 1982) (" 'It is axiomatic that the power to invoke or waive the privilege lies in the corporate client acting through its board of directors or management . . . .") (quoting the court below, 13 Bankr. 54, 67 (Bankr. S.D.N.Y. 1981)); In re Grand Jury Investigation, 599 F.2d 1224, 1236 (3d Cir. 1979) ("If the employees had engaged in questionable activity, the corporation clearly would have the power to waive the privilege and to turn the employees'
} 
When a trustee in bankruptcy seeks control of the attorneyclient privilege to assist him in pursuing litigation in bankruptcy courts, he seeks control of the federal privilege. ${ }^{70}$ In those rare instances in which the trustee seeks control of the privilege for use in state court proceedings, he seeks control of the privilege as it is defined under state law. ${ }^{71}$ For purposes of convenience, this comment will assume that the rules governing the privilege under state law are the same as the federal-law rules. ${ }^{72}$

Federal Rule of Evidence 501, which provides the general rule with respect to privileges in federal proceedings, states that "the privilege of a witness, [or] person . . . shall be governed by the principles of the common law as they may be interpreted by the courts of the United States in the light of reason and experi-

statements over to law enforcement officials . . . ."); Diversified Indus., Inc. v. Meredith, 572 F.2d 596, 611 n.5 (8th Cir. 1978) (en banc) ("Ordinarily, the privilege belongs to the corporation and an employee cannot himself claim the attorney-client privilege and prevent disclosure of communications between himself and the corporation's counsel . . . ."); In re O.P.M. Leasing Servs., Inc., 13 Bankr. 64, 67 (S.D.N.Y. 1981) ("One who communicates with corporate counsel, including an officer, director, shareholder or employee by virtue of his or her role in the corporation, must recognize that it is the corporation, as the client, which may waive or assert the privilege."), aff'd sub nom. Weissman v. Hassett (In re O.P.M. Leasing Servs., Inc.), 670 F.2d 383 (2d Cir. 1982); In re Grand Jury Proceedings, 434 F. Supp. 648, 650 (E.D. Mich. 1977) ("[I]n the absence of any indication to the company's lawyer that the lawyer is to act in any other capacity than as lawyer for the company . . . the privilege is and should remain that of the company and not that of the communicating officer."), aff'd, 570 F.2d 562 (6th Cir. 1978); cf. Kidston, Current Developments in Attorney-Client Privilege, 36 Bus. LAw. 701, 706 (1981) (employees should be given a warning that the corporation might later waive the privilege); Note, The Attorney-Client Privilege: A Look at Its Effect on the Corporate Client and the Corporate Executive, 55 IND. L.J. 407, 411 (1980) (corporation may decide to waive the attorney-client privilege as to previous communications between another officer and the corporation's counsel); Note, The LawyerClient Privilege: Its Application to Corporations, the Rule of Ethics, and Its Possible Curtailment, $56 \mathrm{Nw}$. U.L. REv. 235, 243-44 (1961) (The waiver decision can only be made by someone whose authority is derived from the current board of directors). But cf. Sexton, $A$ Post-Upjohn Consideration of the Corporate Attorney-Client Privilege, 57 N.Y.U. L. Rzv. 443, 509-10 (1982). Professor Sexton argues that the privilege arising from communications between an employee and corporate counsel cannot be disclosed by the corporate counsel unless both the corporation and the employee waive the privilege. If this view is adopted, however, its effect should not be limited to the bankruptcy context. See supra notes 52-62 and accompanying text.

${ }^{70}$ FkD. R. Evm. 501 would govern the privilege in bankruptcy litigation, since the Federal Rules of Evidence apply to evidentiary determinations in the bankruptcy courts. See BANKR. R. 9017; FRD. R. EVID. 101, 1101.

${ }^{71}$ Cf. Weck v. District Court, 161 Colo. 384, 422 P.2d 46 (1967) (trustee seeking control of debtor's accountant-client privilege as defined under state law).

72 Under the analysis developed in this comment, differences in the scope or control of the privilege between state and federal law may be material to whether the trustee may obtain control over the privilege. Where such differences exist, the law that provides the appropriate rules of decision will be determinative. 
ence."78 In the hypothetical situation discussed above, ${ }^{74} A, B$, and $C$, as directors of Debtor Corporation, could, in a nonbankruptcy proceeding governed by federal law, assert Debtor Corporation's attorney-client privilege for the benefit of Debtor Corporation with respect to the privileged communications. Law Firm would then be precluded from disclosing those communications to the law enforcement agency conducting the investigation of Debtor Corporation and its directors. ${ }^{75}$

Nevertheless, the ability of $A, B$, and $C$ to assert Debtor Corporation's attorney-client privilege with respect to the information communicated to Law Firm does not continue forever, even though they were Debtor Corporation's directors at the time the privileged information was given to Law Firm. For example, assume that Law Firm received the same information as in the hypothetical, but instead of a petition in bankruptcy having been filed, Debtor Corporation had convened its annual shareholders' meeting and a new board of directors was elected to replace $A, B$, and $C$. Shortly thereafter, the new board, at the request of the IRS, waived Debtor Corporation's privilege over the objections of $A, B$, and $C$. Because the attorney-client privilege is considered to belong exclusively to the corporation and because the new board can waive or assert the privilege as it chooses, ${ }^{76}$ Law Firm would have to disclose the information despite the protests of the former directors.

The directors of a corporation thus take a certain risk when they give confidential information to the corporation's attorneys. Although they are the agents of the corporation vested with exclusive control over the decision to waive the privilege, they must be aware that such control will last only so long as they remain directors of the corporation. There could be a voluntary or involuntary change in ownership, or management could fall out of favor with the stockholders. ${ }^{77}$ Thus, under nonbankruptcy law, control over the decision to waive or assert the attorney-client privilege belongs

${ }^{73}$ FED. R. Evid. 501.

74 See supra text accompanying notes 16-19.

${ }^{75}$ See In re Grand Jury Proceedings, 434 F. Supp. 648, 649 (E.D. Mich. 1977), aff'd, 570 F.2d 562 (6th Cir. 1978); see also In re O.P.M. Leasing Servs., Inc., 13 Bankr. 54, 57-58 (Bankr. S.D.N.Y.), aff'd, 13 Bankr. 64 (S.D.N.Y. 1981), aff'd sub nom. Weissman v. Hassett (In re O.P.M. Leasing Servs., Inc.), 670 F.2d 383 (2d Cir. 1982).

78 See supra note 69 and accompanying tert.

77 See, e.g., In re O.P.M. Leasing Servs., Inc., 13 Bankr. 54, 57 (Bankr. S.D.N.Y.) ("Existing management may change its collective mind, or there may be a change in management, resulting from a sale of the corporation or because of a voluntary or involuntary transfer of control within the corporation."), aff'd, 13 Bankr. 64 (S.D.N.Y. 1981), aff'd sub nom. Weissman v. Hassett (In re O.P.M. Leasing Servs., Inc.), 670 F.2d 383 (2d Cir. 1982). 
to the corporation itself, not to any particular set of individuals, and can only be exercised by the group of individuals that represents the corporation as directors at the time the decision is made.

With respect to the attorney-client privilege, an individual debtor stands in a much different position than a corporation's directors. Under nonbankruptcy law, only the individual himself has the power to waive his attorney-client privilege; he cannot lose this privilege through the actions of third parties. ${ }^{78}$ This difference between the treatment of corporate directors and individuals results from a fundamental difference between the two types of entities involved. ${ }^{79}$ Unlike an individual, a corporation is an artificial entity that can act only through its agents. Thus, in order to assert or waive its attorney-client privilege, a corporation must place the authority to make the decision in particular agents. Although a corporation's attorney-client privilege exists until it is waived, the authority of any particular agent of the corporation to control the privilege lasts only so long as the agency relationship exists. Thus, unlike an individual's power over his attorney-client privilege, the directors' control of a corporation's privilege rests on their relationship to the corporation rather than on a right that is personal to themselves.

\section{Appointment of a Trustee}

Outside of bankruptcy, the management ${ }^{80}$ of a corporation controls the corporation's attorney-client privilege. ${ }^{81}$ Thus, under the Butner analysis, the trustee should be able to control this privilege if, but only if, he occupies a position analogous to that of new management outside of bankruptcy. The powers of management, as defined by state law and most corporate charters, are extensive. It has complete control over the day-to-day operations of the corporation. ${ }^{82}$ It controls any litigation involving the corporation. ${ }^{83}$

78 See Edward Clrary, McCormick's Handbook on the Law of Evidence \$ 93, at 194 (2d ed. 1972).

70 See, e.g., In re Silvio De Lindegg Ocean Devs. of Am., Inc., 27 Bankr. 28 (Bankr. S.D. Fla. 1982) ("An individual can be sent to prison on the testimony of his attorney divulging a confidence. A corporation cannot suffer any penalty greater than the loss of its fiscal assets ....").

is In practice, a large corporation is typically managed by its top officers, but their legal authority derives from that of the board of directors. See Eisenberg, Legal Models of Management in the Modern Corporation: Officers, Directors, and Accountants, 63 Calr. L. REv. 375 passim (1975). The distinctions generally drawn between officers and directors do not affect the trustee's right to control a debtor's attorney-client privilege.

- See supra notes 67-69 and accompanying text.

a See, e.g., DrL. Cods ANN. tit. 8, \& 141(a) (1983). 
Management is also given authority to make many decisions outside the ordinary course of business. ${ }^{84}$ Along with this extensive grant of power, directors are under certain fiduciary duties, the most important of which is the duty to maximize the corporation's profits for the benefit of its shareholders. ${ }^{85}$

The powers and duties of the trustee in bankruptcy are strikingly similar to those of the corporation's management outside of bankruptcy. The Code gives the trustee the authority to oversee all of the debtor's operations within "the ordinary course of business," value of the debtor's estate for the benefit of the debtor's investors as a group. ${ }^{82}$ Perhaps most relevant to the determination of who controls the debtor's attorney-client privilege is the trustee's power to dictate the course of litigation pending at the time of the filing of the bankruptcy petition, which also mirrors the control given a corporation's board of directors outside of bankruptcy. Bankruptcy Rule 6009 allows the trustee to assume control of any litigation

ss An exception would be shareholder derivative litigation. But even this form of litigation may be subject to control by the board of directors through special litigation committees. The ability of such committees to terminate derivative litigation on behalf of the corporation, however, is unclear under current law. Compare Joy v. North, 692 F.2d 880 (2d Cir. 1982) (in cases where shareholder demand is futile and where the special litigation committee is independent, the committee's decision to terminate the suit will be upheld if the court determines that the cost of litigation exceeds the amount of recovery discounted by the probability of success), cert. denied, 460 U.S. 1051 (1983), with Auerbach v. Bennett, 47 N.Y.2d 619, 393 N.E.2d 994, 419 N.Y.S.2d 920 (1979) (where the members of the committee did not act in bad faith, the "business judgment" rule will apply to their decision to terminate derivative litigation).

os See, e.g., DeL. CoDe ANn. tit. 8, $§ 243$ (1983) (board of directors has the power to retire shares of the corporation's stock); id. $\$ 244$ (providing a number of methods by which the board of directors may alter the corporation's capital structure).

ss The duty of the corporation's directors to maximize profits for the benefit of shareholders has long been recognized. See, e.g., Dodge v. Ford Motor Co., 204 Mich. 459, 507, $170 \mathrm{~N} . \mathrm{W} .668,684$ (1919) ("A business corporation is organized and carried on primarily for the profit of the stockholders. The powers of the directors are to be employed for that end. The discretion of directors is to be exercised in the choice of means to attain that end, and does not extend to a change in the end itself, to the reduction of profits, or to the nondistribution of profits among stockholders in order to devote them to other purposes.").

ss 11 U.S.C. $\$ 363(\mathrm{c})(1)$ (1984 Revision) (CRR) ("[T]he trustee may enter into transactions, including the sale or lease of property of the estate, in the ordinary course of business, without notice or a hearing, and may use property of the estate in the ordinary course of business without notice or a hearing."). Compare this with the description of management's duties in Percival JACKson, Corporate Management § 153c (1955) ("[M]atters that center about the daily and current operations of the business and its administration, are functions to be exercised by the full-time employees and executives of the company, the operating management.").

s7 See supra note 10 and accompanying text. 
that may affect the debtor's estate. ${ }^{88}$ The trustee may even terminate suits in which the expected return to the estate is less than the expected cost of litigation. ${ }^{88}$

If the appointment of a trustee is not to be considered a change in management, the reason for the distinction must lie in the relative powers of the trustee and management to conduct operations outside of the ordinary course of business and in the nature of the duties owed by each to the corporation's residual claimants. The principal distinction between management outside of bankruptcy and the trustee in bankruptcy is the Code's requirement that the trustee obtain court approval for the use, sale, or lease of estate property outside of the ordinary course of the debtor's business. ${ }^{90}$ This restriction contrasts with the much wider

* BANKR. R. 6009 ("With or without court approval, the trustee or debtor in possession may prosecute or enter an appearance and defend any pending action or proceeding by or against the debtor, or commence and prosecute any action or proceeding in behalf of the estate before any tribunal."); see also 11 U.S.C. § 323(b) (1984 Revision) (CRR) ("The trustee in a case under this title has capacity to sue and be sued."); Meyer v. Flemming, 327 U.S. 161, 168 (1946) ("[T] he trustee or receiver, being in a position to take control of the litigation by reason of the fact that the cause of action has become a part of the estate, should have the opportunity to make the choice which is most advantageous to the estate."); 2 Colliks on BANKriptcy \ 323.02 (15th ed. 1984).

- See 2 CollarR ON BANKRUPTCY, supra note 88, at I 323.02. If control over the debtor's attorney-client privilege is vested in the trustee, the trustee must fulfill his duty to maximize the estate's assets by basing any decision to waive the privilege upon a finding that waiver is in the best interest of residual claimants as a group. The trustee would have to weigh the expected costs of releasing the information-for example, criminal penalties that might be assessed against the corporation-against the expected benefits to be gained by bringing the information out into the open-for example, damages that might be recovered on behalf of the corporation in a suit for breach of fiduciary duty against the directors. If the trustee finds that the expected benefits outweigh the expected costs, then he must waive the privilege for the benefit of the estate.

There are many circumstances in which waiver of the attorney-client privilege would be beneficial to the corporation. For example, if the trustee entered into a settlement agreement with the IRS in exchange for release of the privileged information, the debtor's investors would benefit because the agreement would extinguigh a contingent claim against the estate. Moreover, a conviction of the debtor's directors could increase the value of the estate by enhancing the possibility of recovery in a suit against the directors for breach of fiduciary duty.

It should be noted that the decisionmaking method described here for a trustee is identical to the one that a corporate debtor's directors would be under a duty to employ if the decision were vested in them. If the release of the privileged information might lead to recovery against the directors in favor of the corporation, they may be obligated to waive the privilege even against their own interest. See supra note 85 and accompanying text; infra notes 107-14 and accompanying text. While directors have no duty to waive the privilege when only creditors could benefit from any recovery, the trustee does have a duty to waive the privilege for the benefit of creditors. In either case, however, the privilege must be used in a manner that furthers the best interest of the firm's residual claimants.

11 U.S.C. \& 363(b)(1) (1984 Revision) (CRR). 
discretion given to directors in managing their corporations. ${ }^{91}$ This distinction, however, does not justify treating the trustee as something other than the new management of the corporation. It can be explained, rather, as an attempt to reduce agency costs $^{22}$ in bankruptcy to a level equal to those outside of bankruptcy. Code restrictions on the power of the trustee to act unilaterally are bankruptcy's functional equivalent of legal restrictions on management's behavior outside of bankruptcy.

Agency costs arise whenever there is a separation of ownership and control. ${ }^{93}$ Because management's interests and incentives may differ from those of the corporation's investors, there is a risk that the firm's investors will suffer an economic loss-an agency cost-through management behavior that is not in the investors' best interests. ${ }^{94} \mathrm{~A}$ similar agency-cost problem exists within bankruptcy because the trustee's interests may differ from those of the debtor's investors. Outside of bankruptcy, however, mechanisms exist to reduce these costs. ${ }^{95}$ In bankruptcy, these mechanisms no

91 See, e.g., Litwin v. Allen, 25 N.Y.S.2d 667, 678 (Sup. Ct. 1940) (corporate directors are liable for breach of duty only when their decisions do not show a reasonable exercise of business judgment).

92 For a definition of agency costs, see infra note 94 .

os For a discussion of the agency costs associated with the separation of ownership and control, see Easterbrook \& Fischel, Corporate Control Transactions, 91 Yale L.J. 698, 70003 (1982).

4 See Jensen \& Meckling, Theory of the Firm: Managerial Behavior, Agency Costs and Ownership Structure, 3 J. Fin. Econ. 305, 308 (1976) ("[A]gency costs [are] the sum of: (1) the monitoring expenditures by the principal, (2) the bonding expenditures by the agent, (3) the residual loss." (emphasis in original) (footnote omitted)).

It is important to note that when there is a separation of ownership and control agency costs can never be reduced to zero. In order to minimize agency costs, bonding and monitoring mechanisms must be implemented up to the point where their marginal cost equals the marginal savings. For example, management would not spend $\$ 10,000$ to eliminate all employee theft when the maximum losses from such theft would never exceed $\$ 5000$ in the absence of the safeguard. The goal of mechanisms intended to reduce agency costs, both within and outside of bankruptcy, is to reduce the residual loss, but only to the point where it is efficient to do so. Thus, outside of bankruptcy, shareholder approval is required only for certain major decisions made by the board of directors, see infra note 103 and accompanying text, not for decisions concerning the day-to-day operations of the firm. Similarly, bankruptcy law requires that the monitoring mechanism of court approval be used only where the trustee's decisions are made outside "the ordinary course of business." See 11 U.S.C. § 363(b) (1984 Revision) (CRR).

${ }^{\circ 5}$ Mechanisms for reducing agency costs between management and shareholders include the market for corporate capital, the market for corporate control, the market for corporate management, and fiduciary duties imposed by law on corporate directors and officers. See Ralph Winter, Government and the Corporation 7-44 (1978); Fama, Agency Problems and the Theory of the Firm, 88 J. PoL. Econ. 288, 288-98 (1980); Jensen \& Ruback, The Market for Corporate Control, 11 J. Fin. Econ. 5, 29-30 (1983). Agency costs that directly affect the firm's creditors are usually handled by explicit contractual provisions 
longer apply. ${ }^{96}$ Thus, the Code contains provisions designed to assure that the trustee's actions will be in the best interest of the debtor's investors. These provisions deal with four principal agency-cost problems.

First, agency costs increase when the trustee lacks a comprehensive familiarity with the debtor's business and, through ignorance, makes major decisions concerning the debtor's operations that are not in the debtor's best interest. ${ }^{82}$ In order to alleviate this problem, the Code requires court approval for certain decisions, ${ }^{98}$ thus providing an opportunity for parties who are more familiar with the operations of the debtor to have input into important decisions. ${ }^{92}$ In this manner, the Code seeks to ensure that the same expertise that would be used in making major business decisions outside of bankruptcy will be used within bankruptcy.

Second, creditors can ordinarily minimize their agency costs through contractual restrictions on the corporation's ability to dispose of its assets; ${ }^{100}$ in bankruptcy, however, creditors need the special protection afforded by a judicial hearing because the filing of a bankruptcy petition renders many of these contractual provisions unenforceable. ${ }^{101}$ Thus, the Code substitutes the requirement of court approval for the usual contractual safeguards. ${ }^{102}$

intended to constrain management behavior that may be detrimental to the creditors. See infra notes 102, 111 and accompanying text.

* The filing of a bankruptcy petition triggers the Code's automatic stay, 11 U.S.C. \& 362(a) (1984 Revision) (CRR), which prevents claimants from pursuing any remedies against the debtor without leave from the bankruptcy court. Claimants must, therefore, rely on the bankruptcy mechanism to satisfy their claims.

" Outside of bankruptcy, directors can be elected by shareholders for their performance or expertise. The efficiency of corporate management is also checked by market mechanisms, see supra note 95 .

ss See, e.g., 11 U.S.C. $\$ 363(b)$ (1984 Revision) (CRR) (notice and hearing required for the use, sale, or lease of property by the trustee outside the ordinary course of business); id. \$ 364(b) (notice and hearing required for the trustee to obtain unsecured credit outside the ordinary course of business).

" Investors often will have more expertise in the debtor's business than the trustee does. Because any increase in the value of the debtor's assets accrues to the benefit of these investors, they have an incentive to intervene in the bankruptcy proceedings and convince the judge of the merits of their objections to the trustee's proposed actions.

${ }_{100}$ See supra note 95 ; infra note 111.

101 See 11 U.S.C. § 362(a) (1984 Revision) (CRR).

102 See supra note 98 . Private bonding and monitoring mechanisms, freely used outside of bankruptcy, are less feasible within bankruptcy because the creditors have little bargaining power over the trustee. In order to restrain the kinds of behavior within bankruptcy that these mechanisms normally limit outside of bankruptcy, bankruptcy imposes the quasi-public monitoring mechanism of court approval. While monitoring costs are thus increased under either system, the monitoring functions of both systems serve to reduce the residual loss to the firm's investors and thus reduce overall agency costs. 
Third, bankruptcy precludes the use of a shareholder-approval requirement for major transactions. Outside of bankruptcy, merger agreements or agreements to sell a substantial amount of a firm's assets usually require shareholder approval. ${ }^{103}$ This requirement reduces agency costs by directly taking into account the interests of a majority of the shareholders-as indicated by their votesbefore the corporation enters into the transaction. Because the potential economic loss to investors from an erroneous decision by the directors is so great in these situations, the relatively cumbersome mechanism of prior approval is cost-justified. ${ }^{104}$ Bankruptcy eliminates this effective means of controlling agency costs and puts in its place a notice and hearing procedure for certain transactions entered into by the trustee; this procedure assures, before certain transactions are entered into, that decisions made will probably be in the best interests of the residual claimants. ${ }^{105}$

103 See, e.g., DRL. CoDs ANN. tit. 8, \& 251(c) (1983) (requiring shareholder approval of mergers or consolidations between domestic corporations); $i d$. $\$ 271$ (requiring shareholder approval of a sale, lease, or exchange of all or substantially all of a corporation's assets).

104. Other mechanisms for reducing agency costs usually operate by providing ex post remedies for improper behavior. For example, shareholder derivative actions for breach of fiduciary duties or contractual guarantees in loan agreements give directors an incentive to behave properly in order to avoid liability later. Nevertheless, these incentives will not always prevent improper decisions from being made, and it may be difficult to detect breaches or recover damages after the fact. Thus, the requirement of shareholder approval may be worthwhile to prevent breaches before they happen, at least where the stakes are sufficiently high to justify the additional cost. A similar rationale lies behind requirements, in some loan agreements, for prior creditor approval of certain corporate decisions or even for placing a creditor-representative on the board of directors.

${ }^{103}$ The method by which trustees are appointed is also similar to the method by which directors are appointed in nonbankruptcy law. In chapter 7 proceedings, trustees are elected by the creditors, with each creditor's vote being proportionate to his share of the total claim against the debtor. 11 U.S.C $\$ 702$ (1984 Revision) (CRR). Corporate directors are elected by the corporation's shareholders. See, e.g., Det. Cods ANN. tit. 8, § 211(b) (1983). Each shareholder is usually entitled to vote for directors, with the shareholder's vote being proportionate to the shareholder's ownership interest in the corporation. See, e.g., id. \& 212 ("Unless otherwise provided in the certificates of incorporation . . . each stockholder shall be entitled to one vote for each share of capital stock held by such stockholder."); cf. id. \$214 (allowing corporations to provide for cumulative voting in their certificates of incorporation). See generally D. VAGTS, supra note 18 , at 395-413.

In chapter 11 proceedings, a trustee can be appointed pursuant to 11 U.S.C. $\$ 1104$ (1984 Revision) (CRR) when such appointment is in the best interest of the debtor's investors. If a trustee is not appointed, the current management continues to manage the debtor in the capacity of "debtor in possession." Id. \& 1107. Although, in these situations, the decision to appoint a trustee or to leave the debtor in possession is not made pursuant to a vote of claimants, the mechanism is designed to assure that the decision will be made in their best interests.

Trustee-removal procedure is also similar to the removal of directors in nonbankruptcy law. Trustees may be removed by the bankruptcy court after notice and a hearing. See id. $\$ \S 324,1105$. Similarly, directors may be removed by a vote of a majority of shareholders on 
Finally, the trustee is more closely scrutinized by courts and owners than are directors outside of bankruptcy because the most effective control over the agency costs that are caused by directors' behavior is absent in bankruptcy: there is nothing like the market for corporate management or corporate control that exists outside of bankruptcy. Outside of bankruptcy, if the managers of a corporation fail to run the corporation effectively, they may be replaced by more effective directors either through a vote of dissatisfied existing shareholders or through a change of corporate control facilitated by lower prices for the corporation's stock. ${ }^{108}$ This mechanism provides the greatest assurance that, outside of bankruptcy, the managers of a corporation will pursue goals that are in the best interests of the corporation's shareholders. Outside of bankruptcy, the markets for corporate control and corporate management reduce the shareholders' agency costs; inside of bankruptcy, the opportunity for judicial review and the requirement of notice to all investors, including residual claimants, serve as substitute mechanisms for controlling these agency costs.

Since the Code grants the trustee powers analogous to those of management outside of bankruptcy, the only reason for not treating the trustee as new management would have to be that the trustee's duties differ significantly from those of new management, thus indicating that the trustee might waive or assert the attorneyclient privilege in a different manner than would new management. But an analysis of the duties of the trustee in bankruptcy reveals that they are similar to those imposed on a corporation's management. Outside of bankruptcy, a corporation's management owes a fiduciary duty to the shareholders to maximize the corporation's profits. ${ }^{107}$ Similarly, trustees in bankruptcy have a duty to the debtor's investors to maximize the assets of the estate. ${ }^{108}$

the specific question of the director's removal, see, e.g., DsL. CoDE ANN. tit. 8, $\S 141(\mathrm{k})$ (1983), or by shareholder approval of other nominees for director at the shareholders' meeting, see, e.g., id. $\$ 211(\mathrm{~b})$.

${ }^{100}$ [The] divergence of interests between principals and agents may be controlled by the operation of the employment market. An unfaithful or indolent agent may be penalized by a lower salary, and a diligent agent may be rewarded by a bonus for good performance. In addition, the threat of sales of corporate control induces managers to perform well in order to keep their positions. Finally, competition in product markets helps to control agents' conduct, because a poorly-managed firm cannot survive in competition with a well-managed firm (other things being equal).

Easterbrook \& Fischel, supra note 93, at 701; see also Fama, supra note 95, at 288-98; Jensen \& Ruback, supra note 95, at 6-7. Trustees, on the other hand, may be removed only for cause, see 11 U.S.C. $\$ 324$ (1984 Revision) (CRR), and are not threatened by takeovers.

107 See supra note 85. These duties are generally imposed by state law.

${ }_{108}$ See supra note 10; see, e.g., Commercial Credit Corp. v. Skutt, 341 F.2d 177, 181 
There is a distinction between the categories of investors to whom the corporate directors and the trustee in bankruptcy owe their duties: the fiduciary duties of corporate directors run to shareholders, not creditors, while creditors' rights are the dominant concern of a bankruptcy trustee. ${ }^{100}$ This distinction, however, is one of terminology rather than substance. When a debtor enters bankruptcy, it is usually because the debtor is insolvent-i.e., it cannot satisfy all claims against its assets. ${ }^{110}$ The purpose of the trustee's duty to maximize the estate's assets is to assure that the greatest possible sum is made available to satisfy those claims. Outside of bankruptcy, creditors can protect their claims on the corporation through contractual provisions such as "events of default," 111 which trigger an immediate obligation by the corporation to pay off the debt in full when certain events occur. These clauses

(8th Cir. 1965) ("[The trustee] has the duty to call to the court's attention any error in an order affecting the estate...."); In re Washington Group, Inc., 476 F. Supp. 247 (M.D.N.C. 1979) (bankruptcy court and the trustee exceeded authority by authorizing funds to be spent from the debtor's estate in order to subsidize litigation that could result in no benefit to the estate and was, therefore, adverse to the interests of both stockholders and creditors), aff'd sub nom. Johnston v. Collins, 636 F.2d 1213 (4th Cir. 1980), cert. denied, 425 U.S. 940 (1981); Second Nat'l Bank v. Marcincin (In re Nadler), 8 Bankr. 330, 332 (Bankr. E.D. Pa. 1980) ("The trustee's fiduciary obligation to conserve estate assets, so as to maximize distribution to creditors, is also implied by other duties imposed upon him by the bankruptcy law . . . ."); cf. United States ex rel. Willoughby v. Howard, 302 U.S. 445, 454 (1938) (the trustee in bankruptcy has a duty to use ordinary care in the making of deposits and a failure in this respect will give rise to liability).

${ }^{109}$ See supra notes 10 \& 85.

110 The Code defines "insolvent" for an entity other than a partnership as

[a] financial condition such that the sum of such entity's debts is greater than all of such entity's property, at a fair valuation, exclusive of-

(i) property transferred, concealed, or removed with intent to hinder, delay, or defraud such entity's creditors; and

(ii) property that may be exempted from property of the estate under section 522 of this title....

11 U.S.C. § 101(29)(A) (1984 Revision) (CRR).

III Exactly what constitutes an "event of default" is usually negotiated as part of a loan agreement:

The objective in specifying events of default in a loan agreement is to describe those circumstances in which the lender (or a percentage of lenders) should have the right to terminate the lending relationship-that is, the right to terminate the lending commitment and to declare due and payable any outstanding loans. . . . This right is primarily important to bank lenders for getting the attention of and negotiating with a financially or otherwise troubled borrower, or with other creditors of that borrower, in order to effect other measures, like restructuring the credit, or obtaining guaranties or collateral or other credit support, or selling assets.

Ryan, Defaults and Remedies under International Bank Loan Agreements with Foreign Sovereign Borrowers-A New York Lawyer's Perspective, 1982 U. In. L. REv. 89, 90. For a discussion of some specific examples of events of default, see $i d$. at 90-100. 
become unenforcable once a bankruptcy petition is filed.112 Once the corporation enters bankruptcy, creditors (much like shareholders outside of bankruptcy) must rely on the expertise and good faith of those who control the corporation's affairs to preserve their capital. Outside of bankruptcy, the reliance of shareholders on the judgment of the corporation's directors is supported by the directors' duty to maximize profits. By imposing upon the trustee a duty to maximize the estate's assets, the Code compensates the creditors for their inability to rely on the contractual protection they enjoyed outside of bankruptcy.

Directors and trustees thus seek to accomplish the same goal for the corporation: achieving the greatest return for the residual claimants of the enterprise. Because agency costs tend to increase when a debtor enters bankruptcy, the Code provides mechanisms for decreasing these costs. As a result, the trustee occupies a position that closely approximates the position of a director before the filing of a bankruptcy petition.

Because the trustee finds himself in a situation similar to that of new directors outside of bankruptcy, and because a new board of directors has the power to waive the corporation's attorney-client privilege, the Butner analysis ${ }^{113}$ requires that the trustee be permitted to control the debtor's attorney-client privilege. If the trustee's power to control the attorney-client privilege differed from the power to control the privilege enjoyed by a new board of directors outside of bankruptcy, there would be a substantive change in the rights of the parties due to the mere happenstance of bankruptcy. The Supreme Court's decision in Butner prohibits such a change. ${ }^{114}$

V. Objections to Allowing the Trustee to Control the Atrorney-Client Privilege: Commodity Futures Trading Commission v. Weintraub

In Commodity Futures Trading Commission v. Weintraub, ${ }^{115}$ the Seventh Circuit held that the trustee does not control the corporate debtor's attorney-client privilege. The court gave several

11311 U.S.C. $\S 362(a)$ (1984 Revision) (CRR). The changes in the rights of parties caused by the automatic stay are necessary for a collective proceeding. In order to avoid a piecemeal liquidation of the estate, the stay prevents parties from pursuing their state-law remedies.

${ }^{113}$ See supra notes $46-63$ and accompanying text.

114 See supra notes 52-53 and accompanying text.

116 722 F.2d 338 (7th Cir. 1984), cert. granted, 53 U.S.L.W. 3310 (U.S. Oct. 30, 1984) (No. 84-261). See supra notes $36-42$ and accompanying text. 
justifications for its conclusion; perhaps the most compelling is the argument that because the trustee should not be permitted to waive an individual debtor's attorney-client privilege, permitting a trustee to waive a corporate debtor's privilege would result in discriminatory treatment of corporations. This section will examine the Seventh Circuit's arguments, and will in particular show why disparate treatment of corporate and individual debtors is appropriate.

\section{A. The Problem of Individual Debtors}

The Weintraub court argued that a rule allowing the trustee to waive a corporate debtor's attorney-client privilege would have to apply in the case of an individual debtor as well. ${ }^{116}$ Because it would be "absurd" to permit a trustee, who may conduct a public examination of an individual debtor, ${ }^{117}$ to waive the individual's privilege during such an examination, the court concluded that the trustee could never waive the privilege on behalf of either a corporate or an individual debtor. ${ }^{118}$ One court, however, has allowed the trustee to waive the individual debtor's attorney-client privilege; ${ }^{118}$ in so doing, it relied on cases that allowed the trustee to waive a corporate debtor's attorney-client privilege. ${ }^{120}$

The problem with both lines of analysis is the assumption that individual and corporate debtors must be treated alike, when in fact there are compelling reasons for applying a different rule in each case. ${ }^{121}$ The trustee should be allowed to waive the corporate debtor's attorney-client privilege because the appointment of a trustee in that context is analogous to a change in management outside of bankruptcy. There is no corresponding "management," however, to direct the affairs of an individual outside of bankruptcy. ${ }^{122}$ Thus, the trustee should be permitted to waive an individual debtor's attorney-client privilege only if some other, analo-

110722 F.2d at $342-43$.

${ }^{117}$ See 11 U.S.C. § 343 (1984 Revision) (CRR).

118722 F.2d at 343.

110 In re Smith, 24 Bankr. 3 (Bankr. S.D. Fla. 1982).

${ }^{120}$ Id. at 5.

${ }^{121}$ Indeed, the fact that Congress has established separate rules for bankruptcies of corporations and individuals, compare 11 U.S.C. chs. 7, 11 (1984 Revision) (CRR) (liquidation and reorganization of corporations) with id. ch. 13 (adjustment of debts of individuals), implies that rules developed in one context should not be automatically applied in the other.

128 Assuming, of course, that the individual is not incompetent, an infant, or otherwise under the guardianship of another. 
gous nonbankruptcy situation leads to a similar result.

The trustee of an individual debtor assumes control over most of the assets of that individual, just as he does in the case of a corporate debtor. ${ }^{123}$ The trustee, however, does not control the individual himself; he cannot force the debtor to work, to change jobs, or to do anything the individual debtor does not wish to do. The trustee, in effect, has no more control over the activities of an individual debtor than does a person who has purchased all of that person's assets: he is only given the power to control the use of the assets. The mere transfer of assets from one person to another does not entail the transfer of the individual's attorney-client privilege as well. ${ }^{124}$ Thus, the change that occurs when an individual enters bankruptcy is analogous to a sale of assets outside of bankruptcy, which does not affect the individual's ability to control the attorney-client privilege. The trustee should therefore have no power to waive an individual debtor's attorney-client privilege.

This difference in the treatment of corporations and individuals also makes sense in light of the nature of the attorney-client privilege outside of bankruptcy. Outside of bankruptcy, corporate directors may only assert the corporation's attorney-client privilege in their capacity as agents of that entity. ${ }^{125}$ When an individual asserts his attorney-client privilege, however, he is asserting a privilege that is personal to him. ${ }^{126}$ Because directors who try to assert the corporation's attorney-client privilege occupy a different position vis-à-vis the holder of the privilege than does an individual asserting his own privilege, it is not surprising that nonbankruptcy law should treat corporate directors and individuals differently. Thus, the argument in Weintraub-according to which a trustee's power to waive the attorney-client privilege of a corporate debtor would discriminate against corporations-is fundamentally unsound: it completely neglects the nonbankruptcy difference, which should be reflected in bankruptcy law, between directors asserting a corporation's privilege and an individual asserting his own privilege.

${ }^{122}$ See, e.g., 11 U.S.C. $\$ 1302$ (1984 Revision) (CRR) (granting the trustee power to administer the individual debtor's estate); $i d . \$ 1306$ (defining property of the estate in individual bankruptcies).

124 See supra note 34 and accompanying text.

184 See supra notes 75-77 and accompanying text.

12e See supra notes 78-79 and accompanying text. 


\section{B. Other Objections}

The Weintraub court also examined the role of the trustee, and concluded that the trustee was not like new management and that the trustee should therefore have no power to control the debtor's attorney-client privilege. ${ }^{127}$ The court's reasoning, however, relied too heavily on labels. Relying upon the premise that the trustee does not replace the corporation as a legal entity and does not assume the legal office of the current corporate management, the court formalistically reasoned that the trustee fails to succeed to the powers that are associated with those positions. ${ }^{128}$ This analysis ignores the reality of the transformation that occurs when a corporation enters bankruptcy and is placed under the control of a trustee. ${ }^{129}$ The powers and duties given to the trustee are so wide-ranging ${ }^{130}$ that it is unrealistic to characterize the trustee as anything other than new management. ${ }^{131}$ Thus, this justification put forth by the Weintraub court for denying the trustee the power to waive the attorney-client privilege carries little force.

The Seventh Circuit also refused to allow the trustee to waive the debtor's attorney-client privilege because it perceived that such a holding would amount to discrimination among corporations based on their economic status. ${ }^{132}$ The court argued that solvent corporations would be allowed to assert or to waive their privileges

127722 F.2d at 342.

128 Id.

129 In Weissman v. Hassett (In re O.P.M. Leasing Servs., Inc.), 670 F.2d 383, 386-87 (2d Cir. 1982), the court relied upon the fact that the corporate debtor's directors had resigned, leaving no representative of the estate other than the trustee, to conclude that the trustee could waive the debtor's attorney-client privilege. The Weintraub court distinguished Weissman on the ground that one of the directors was still in office and was thus capable of waiving or asserting the privilege. Weintraub, 722 F.2d at 341 . This factual distinction, however, is irrelevant since it has nothing to do with the reasons for appointing the trustee in the first place. The trustee becomes the new management of the debtor precisely because the checks on the behavior of the old management are no longer effective to safeguard the interests of the corporation's new residual claimants. See supra notes 95-107 and accompanying text. To the extent that any checks would exist at all, old management would only be bound to exercise control over the privilege in the interests of the corporation's "shareholders." Thus, in a situation in which old management, rather than the trustee, was allowed to control the privilege, there would be no mechanism for ensuring that the privilege would be exercised in the best interests of other investors (especially other residual claimants), who usually have a greater stake in the benefits to be derived.

130 See supra notes 86-89 and accompanying text.

1s1 See In re O.P.M. Leasing Servs., Inc., 13 Bankr. 54, 58 (Bankr. S.D.N.Y.) ("[T]he trustee possesses and controls [the corporate debtor's] affairs, and subordinate management, if any, serves at the trustee's pleasure."), aff'd, 13 Bankr. 64 (S.D.N.Y. 1981), aff'd sub nom. Weissman v. Hassett (In re O.P.M. Leasing Servs., Inc.), 670 F.2d 383 (2d Cir. 1982).

133722 F.2d at 343. 
by action of their elected officers while insolvent corporations would be forced to bend to the will of the trustee. ${ }^{138}$ Implicit in this argument is the assumption that the trustee will exercise the debtor's attorney-client privilege to the detriment of the corporation, while the debtor's directors will not. This assumption, however, ignores the safeguard that is provided by the duties placed upon the trustee. In the same way that the directors of the corporation, outside of bankruptcy, would be required to waive the privilege if the net result would be to increase profits, ${ }^{194}$ the trustee should be permitted to waive the privilege if the result would be to increase the assets of the estate. ${ }^{135}$ Because the trustee's duties are aligned with the interests of a corporate debtor's residual claimants in the same way that the duties of management outside of bankruptcy are aligned with those of the shareholders, no "discrimination" against insolvent corporations would result from a rule that gives the trustee control over the attorney-client privilege.

Finally, the Seventh Circuit asserted that allowing the trustee

12s Id. The court did not explain how the existence of such discrimination was relevant to the analysis. Apparently, the court felt that it would somehow amount to unfair treatment of insolvent corporations. But a vague notion of unfairness is altogether unhelpful in this context. A court might use a similar argument to deny a petition to place an insolvent corporation into bankruptcy involuntarily; healthy corporations, after all, cannot be so "unfairly" treated.

If notions of "fairness" are to be introduced, the inquiry should focus on which categories of individuals are unfairly treated by a change in the substantive rules occasioned by the filing of a bankruptcy petition. Under the rule adopted by the court in Weintraub, the only parties who get an advantage are the debtor's directors: they may retain control over the attorney-client privilege, while in an analogous nonbankruptcy situation, they would lose such control. Conversely, the debtor's residual claimants are disadvantaged because the privilege might not be waived even though it would be in the best interest of the residual claimants to do so.

12 This would be required under the directors' duty to maximize profits for the benefit of shareholders. See supra notes $85,89,107$ and accompanying text. The directors would probably have a duty to waive the privilege, for example, if the resulting penalties that might be assessed against the corporation would be less than the damages the corporation might recover in a suit against one of the directors for breach of duty. See supra note 85 and accompanying text. The duty could exist even if the directors would be releasing information against their personal interests; failure to waive the privilege solely to avoid personal liability could amount to self-dealing and thus be actionable by the corporation's shareholders. Cf. Tourea Land \& Cattle Co. v. Linsenmeyer, 100 Ariz. 107, 122, 412 P.2d 47, 57 (1966) (in banc) (if a corporate officer "has a specific duty to act in regard to a particular matter as a representative of the company" then he may not use that matter for his own benefit); Equity Corp. v. Milton, 42 Del. Ch. 425, 431, 213 A.2d 439, 442 (1965) (the question is whether the corporate fiduciary "has appropriated for himself something that in fairness should belong to his corporation"); Guth v. Loft, Inc., 23 Del. Ch. 255, 270, 5 A.2d 503, 510 (Sup. Ct. 1939) ("[T]here shall be no conflict between duty and self-interest.").

125 See supra notes 10, 89 and accompanying text. 
in bankruptcy to waive a corporate debtor's attorney-client privilege would have a chilling effect on pre-petition communications between corporate agents and corporate counsel because of a fear of future bankruptcy. ${ }^{136}$ This argument, however, loses sight of both the purpose of the attorney-client privilege and the intended beneficiary of the privilege in nonbankruptcy law. The attorneyclient privilege strikes a delicate balance between two competing demands: the need for full disclosure of information in order to adjudicate disputes between parties and the need for clients to be given adequate legal assistance from fully informed counsel. ${ }^{137}$ In the corporate context, the attorney-client privilege allows the current employees of a corporation to discuss matters freely with corporate counsel; they engage in these discussions in their capacity as the agents of the corporation's owners, for the benefit of those owners. Under the balance struck by the privilege in nonbankruptcy law, the decision as to whether information will be disclosed is left solely to the corporation's current management. At any given time, only the agents immediately responsible for the management of the corporation may assert the privilege; no other parties may block the disclosure of information from the corporation's counsel. ${ }^{138}$ As a result, the former directors of a corporation cannot prevent the disclosure of information that they gave to the corporation's counsel during their directorships.

The propriety of the balance that has already been struck in

136 722 F.2d at 343.

137 See supra notes 64-65 and accompanying text.

1s3 See supra notes 75-77 and accompanying text. Communications to corporate counsel concerning actions by a corporation's employees raising the prospect of liability for both the corporation and the employee may be an exception. The general rule is that when an employee communicates with corporate counsel on a matter involving the corporation, the privilege belongs to the corporation unless the individual has established a personal attorneyclient relationship with the counsel. See United States v. Piccini, 412 F.2d 591, 593 (2d Cir. 1969); Comment, The Application in the Federal Courts of the Attorney-Client Privilege to the Corporation, 39 FordhaM L. REv. 281, 293 (1970). This rule has the effect of forcing the employee to raise the issue of individual representation, thereby allowing corporate counsel to decline such representation if he feels there could be a conflict. See Moder Code or Professional Responsibility EC 5-18 (1981). If a personal attorney-client relationship exists between the employee and the corporate counsel, however, the corporation may not force counsel to disclose information covered by the individual privilege without the consent of the employee. See In re Boileau, 736 F.2d 503, 506 n.1 (9th Cir. 1984); Continental Oil Co. v. United States, 330 F.2d 347, 348-50 (9th Cir. 1964). While the addition of an attorney-client relationship between corporate counsel and an employee or director would complicate the situation, it would not alter the analysis presented in this comment. If the privileged information is also within the scope of the employee's own attorney-client privilege, waiver by the trustee would be subject to the same conditions, including consent of the individual, as would waiver by management outside of bankruptcy. 
nonbankruptcy law between the need for disclosure and the need for consultation is not a bankruptcy question. Nor is it a concern of bankruptcy law to determine whether it is appropriate for directors to be faced with the possibility that at some later time they may no longer control the corporation's attorney-client privilege. Such considerations are the proper concern only of nonbankruptcy law. As a procedural mechanism designed to facilitate a collective proceeding, bankruptcy should do nothing more than mirror the rights that the parties would have had in the absence of the filing of a bankruptcy petition. ${ }^{139}$ The chilling effect on communications emphasized by the court in Weintraub is not a creation of bankruptcy law; rather it is the result of the nonbankruptcy rule that allows only the current agents of the corporation to waive the privilege. Butner and the principles underlying a collective proceeding require that bankruptcy law reflect nonbankruptcy rights; those rights should not be reallocated in a manner thought to be more desirable apart from considerations unique to the bankruptcy mechanism. ${ }^{140}$ Thus, in considering the chilling effect that would result from giving trustees the power to control the attorney-client privilege, the Seventh Circuit was not providing an argument that has any special relevance to bankruptcy. It was, rather, an argu-

139 See supra notes 57-62 and accompanying text; cf. Butner v. United States, 440 U.S. 48, 56 (1979) ("[T]he federal bankruptcy court should take whatever steps are necessary to ensure that the mortgagee is afforded in federal bankruptcy court the same protection he would have under state law if no bankruptcy had ensued.").

130 It might be argued that a consideration unique to bankruptcy does indeed exist in this context because the chilling effect on disclosure by management would be especially strong immediately prior to the filing of a bankruptcy petition-just when a corporation's management is most in need of the advice of informed counsel. See 73 ILI. B.J. 112, 116 (1984). Such an argument, however, is insufficient to justify an alteration of the nonbankruptcy rule within bankruptcy because such situations do not in fact arise only in the bankruptcy context. There are similar instances outside of bankruptcy where informed legal advice is critical to the corporation's management, while at the same time loss of control of the attorney-client privilege by the existing directors may be imminent. An example of this arises when a corporation is the target of a hostile tender offer. The directors of the target corporation need to know what legal measures they can can take to resist the takeover attempt, but it is well-settled that, if the takeover is successful, the new management will have control of the corporation's attorney-client privilege with respect to communications taking place prior to the takeover, see supra note 76 and accompanying text. There is no reason to suspect that the chilling effect on communications or the need for informed legal advice would be any greater in the imminent-bankruptcy situation than in the imminenttakeover situation; thus, it would be improper to upset within bankruptcy the balance already struck by nonbankruptcy law. The point is strengthened by noting the perverse incentives that would result from using different rules in these two very similar contexts: if a hostile takeover attempt appeared likely to succeed, the corporation's directors would have an incentive to file a petition for bankruptcy in order to maintain control over the attorneyclient privilege with respect to earlier communications. See supra notes 55-56. 
ment that should first be addressed to the underlying nonbankruptcy rule.

\section{Conclusion}

Under the Supreme Court's decision in Butner $v$. United States, the appropriate starting place in deciding whether the trustee has the power to waive a debtor's attorney-client privilege is nonbankruptcy law. Under nonbankruptcy law, only the current directors of a corporation control the corporation's attorney-client privilege, while an individual has complete and permanent dominion over his own privilege. Because the appointment of a trustee within bankruptcy is equivalent to a change in corporate management outside of bankruptcy, the control of the corporation's attorney-client privilege should pass to the trustee. In the case of an individual debtor, however, the appointment of a trustee in bankruptcy resembles a mere sale of assets outside of bankruptcy. Thus, the trustee should not be able to assert or waive an individual's attorney-client privilege.

William R. Mitchelson, Jr. 